\title{
Література:
}

1. Вергун Н. Виставка творів (етюди,малюнки,ескізи): Каталог / Автор передм. Н. Вергун. Х.: ХХМ, 2008. 34 с.

2. Вергун Н. Етюди. Малюнки: Альбом / Автор передм. Н. Мизгіна. Х. : ТОВ «Майдан», 2009.

3. Владич Л. Тетяна Нилівна Яблонська. К.: Державне видавництво образотворчого мистецтва і музичної літератури УРСР, 1958. $64 \mathrm{c}$.

4. Немцова В. С. Проблема становления стиля в живописи Натальи Вергун / В. С. Немцова / Вісник Харківської державної академії дизайну і мистецтв . Мистецтвознавство. Архитектура. 2009. № 5. С. 135-145

5. Скляренко Г. Імпресіонізм в українському живописі. Особливості інтерпретації художнього досвіду / Мистецтвознавство України. К.: Спалах, 2010. Вип. 11. С. 16-22.

\section{DOI https://doi.org/10.30525/978-9934-26-178-7-30}

\section{КОНЦЕПЦІЯ САКРАЛЬНОГО У ЖИВОПИСІ ОЛЕКСАНДРА КОДЕНКА}

\author{
Жосул В. I. \\ аспірант кафедри теорї і історії мистецтв \\ Харківська державна академія дизайну і мистеитв \\ м. Харків, Украӥна
}

Релігійне мистецтво завжди займало особливе місце в українській культурі. Нова інтерпретація сакральної тематики пропонує глядачеві новий погляд на тему релігії у світі. Сакральна тематика в живописі сучасних українських мистців $\epsilon$ спробою зберегти i водночас переосмислити традиції.

Нову репрезентацію релігійної тематики демонструє творчість луганського живописця Олександра Івановича Коденка (1942- 2021 рр.). Своєрідна філософія художника стала основою його творчості. Вона складалась в процесі синтезування східної духовності, арійського космологізму та християнської релігії. Присвятивши свою творчість філософсько-релігійному осмисленню світу, автор звернувся до медитативного живопису. 
Особистість О. Коденка формувалась під впливом київської живописної школи, а особливо його вчителя В. Г. Пузиркова. Роботи художника тривалий час мали соцреалістичну спрямованість, що відповідало вимогам офіційного мистецтва того часу, коли відбувалося становлення творчої особистості мистця. Глобальні трансформації творчості О. Коденка припадають на 1990-ті роки, час, коли відбувається становлення принципів нового ненаративного живопису в українському мистецтві. Зміни орієнтирів творчості пов'язані з формуванням нових релігійно-філософських засад художника, які вплинули на його звернення до трансцендентальної медитації. На ії̈ основі формувався так званий медитативний живопис художника.

Творчий метод О. Коденка спирається, передусім, на принцип синтетичності. За допомогою звернення до різноманітних технік складається низка стилістичних особливостей художньої мови мистця, як : лаконічність та м'якість кольорової палітри, формування образів тоном або фактурою фарби, гра 3 геометричними формами, які мають символічне значення [1, с.38].

Сакральну тематику художник розкриває в багатогранній семіотичній системі, яка грає першочергову роль в полотнах мистця. Активне використання знаків, символів, образів християнського іконографічного канону, сакральної геометрії та нумерології створюють складну за структурою символічну систему його творів.

Формування семіотичної системи в творчості О. Коденка тісно пов'язане з пошуком власних світоглядних засад і проявляється у спробі осягнути буття в категорії філософсько-метафізичного досвіду. Саме на основі метафізичного пошуку автор звертається до медитативного живопису. В полотнах це позначилось на засобах художнього мовлення, яким віддає перевагу мистець. Абстрактний живопис служить спробою зобразити власний метафізичний досвід в сакральному руслі, формуючи на цьому власну семіотику, яка має релігійні знаки, образи та власні символи, такі як коло, квадрат, квітка, «квітка життя», лист, піраміда, свічка, човен, яблуко, гранат, чаша, образи святих, Христа, янгола, голуба, жінки та ін. Мистець активно використовував символи візантійської ікони, а також створював власні, звертаючись не тільки до християнської символіки, а й до інших джерел, таких як сакральна геометрія, надаючи класичним сюжетам нове осмислення та трактування.

Синтез є основою творчості О. Коденка: міксування різних художніх засобів виразності в поєднані зі зверненням до старовинної християнської, буддистської символіки, західної нумерології та сакральної геометрії складає багатогранну семіотичну систему мистця. 120 
Колір же на його полотнах є не тільки засобом художньої виразності, а повноцінним символом. Сакральну тематику художник репрезентує як космічну мандрівку та завуальовує прямий авторський підтекст у технічних прийомах, символах та образах. Нетрадиційні техніки стали дійовими засобами до моделювання нової духовної творчості. У своїх медитативних творах О. Коденко поєднує засоби як фігуративного, так $\mathrm{i}$ абстрактного живопису, а багатогранна семіотична система включає в себе сакральну геометрію, нумерологію та класичні біблійні образи, які роблять полотна художника загадкою для глядача.

\title{
Лiтература:
}

1. В’ячеславова О. Жити в просторі, відкритому до неба. Поетика композиції О.Коденка. Образотворче мистецтво. 2003. № 3. С. 38-40.

2. Коденко А. Квадратура бесконечного круга: Альбом. Луганск : 2019. 80 с.

3. Коденко А. Сойдите к подножию истины, откройте двери вечные. Живопись: Альбом. К.: 2010. 300 с.

\section{DOI https://doi.org/10.30525/978-9934-26-178-7-31}

\section{МАТЕМАТИКА В МИСТЕЦТВІ: ВІД ЗОЛОТОГО ПЕРЕРІЗУ ДО ФІРСТАЇЗМУ}

\author{
Маслюченко Г.-Ж. Я. \\ магістр мистеитвознавства \\ м. Чернівці, Україна
}

Вступ. Про взаємозв'язки математики і мистецтва відомо давно. Так, стаття «Математика і мистецтво» у Вікіпедії вказує на те, що «математика існує в таких мистецтвах як музика, танець, малярство, архітектура, скульптура та текстиль». Звичайно, сюди слід долучити ще хоча б літературу.

Глибинні взаємозв'язки між мистецтвом і математикою добре розумів німецький письменник Герман Гессе, автор чудової книги про Гру в бісер [1], «у якій математика і музика грали однакову роль і яка давала змогу поєднувати астрономічні і музичні символи, зводити математику і музику, так би мовити, до спільного знаменника» [1, с. 49]. Придумана письменником Гра в бісер як образ інтелектуальної 